\title{
Research on the Development of Growth Enterprise Market in China
} Yitong Niu*

Sofia University, CA 92626, USA. E-mail: itong_niu@163.com.

Abstract: In this paper, firstly, the definition and market positioning development of GEM are summarized, and the current situation of GEM development is analyzed. At the same time, compared with the main board market, overseas GEM and mature American market, it is found that the GEM market is gradually approaching the standards of overseas markets in terms of IPO, but this is not an act of spontaneous regulation of market system because of the rapid issuance of new shares. So there is no stability, and it is still necessary to continue to make efforts in the construction of various systems. Finally, the paper puts forward some suggestions on the development of China's GEM market, namely, actively learning from the successful development experience of overseas GEM markets and setting clear targets according to market positioning.

Keywords: Growth Enterprise Market; Present Situation Analysis; Counter Measures

\section{Overview of the growth enterprise market}

\subsection{Definition of growth enterprise market}

The original Chinese name of GEM comes from the GEM market of Hong Kong Stock Exchange, China, which refers to the market that specially assists high-growth emerging innovative companies, especially high-tech companies to raise funds and carry out capital operation, and some of them are also called second board market, alternative stock market, growth stock market, etc. Although NASDAQ, the predecessor of GEM, was founded in 1997, but the real development of GEM began with the worldwide industrial innovation brought by the rise of computer industry. Since 1990, with this new technological revolution, there has been a wave of entrepreneurship in global new technology industries. Driven by this wave, there are many GEM markets in more than 50 countries around the world. Except a few of these markets appear in the form of independent markets, most of them belong to the securities market under the main board market, which is generally called the second board market. Although these markets are different in form and size, they are called GEM in this paper ${ }^{[1]}$.

\subsection{Comparison between GEM and main board market}

The functional design of GEM is different from the starting point of main board market, which mainly serves small and medium-sized enterprises with high growth potential. These enterprises can only be listed on GEM because they cannot meet the main board listing standards. First; In terms of business time limit. The listing standard of GEM is relatively short, and the minimum profit requirement is not set or very low. For many GEM markets, the listing standards generally require listed companies to operate for more than three years and provide complete financial annual reports for the last three years. For those who have been operating for no more than three years, it is generally required to provide a complete annual financial report of the completed year. Second, it's about the scale of enterprise equity. The list-

Copyright (C) 2021 Yitong Niu

doi: $10.18686 /$ fm.v6i1.3175

This is an open-access article distributed under the terms of the Creative Commons Attribution Non-Commercial License (http://creativecommons.org/licenses/by-nc/4.0/), which permits unrestricted non-commercial use, distribution, and reproduction in any medium, provided the original work is properly cited. 
ing standards of GEM are relatively small. Generally, the requirement for the total share capital is about 20 million to 30 million. Third, it's about the main business of the enterprise. The listing standard of GEM requires GEM enterprises to generally operate a main business. Because of the small scale of the enterprise, a clear and single business can have a clearer expectation for its future development ${ }^{[2]}$.

\section{Market positioning and development of China's GEM}

\subsection{Relationship between main board market and growth enterprise market}

At present, there is no transfer system in China's Growth Enterprise Market, so there is no flow of listed companies between the two markets. Traditional market and emerging market have obvious division of labor in listing resources, which complement each other in a certain sense and enrich the content of capital market together. Small and medium-sized enterprises come to the market, which have higher growth potential, but also have higher risks. This characteristic of listed companies in GEM also determines that investors in GEM should not only have richer market analysis ability, but also have stronger ability to bear risks. In contrast, due to the higher listing standards in the main board market, its listed companies basically belong to the relatively mature industrial fields, and due to their large scale, their development is relatively stable and their fluctuations are relatively small. Therefore, the requirements for market investors are slightly lower, and the capital and income in the market are also in a relatively stable state. Another relationship between traditional market and emerging market is that emerging market is a reference for the development of traditional market. In the process of establishing China's GEM market, it not only draws lessons from the experience of foreign GEM markets, but also fully summarizes the successful and insufficient experiences and lessons of China's main board market for many years. The development of China's main board market provides a useful reference for the GEM market. From the development of NASDAQ market and New York Stock Exchange market, the history of mutual reference between them has a long history, which also shows that the development of GEM can also provide some help and supplement for the development of the main board market.

\subsection{Analysis on the mechanism of china's growth enterprise market}

China's Growth Enterprise Market adopts the same IPO issuing mechanism as the main board-inquiry system. Including the United States, Britain, Germany, France and many other European and American countries, the stock market IPO adopts the cumulative bidding inquiry system. Among them, the American cumulative order inquiry mechanism is even considered as a sharp weapon for the transnational competition of American investment banks. Compared with other IPO issuance mechanisms, this mechanism has better flexibility and can give issuers and underwriters greater process control rights in the IPO issuance process; Under this mechanism, underwriters can negotiate with investors with information to ensure that a sufficient number of investors participate in the subscription of new shares, thus reducing the uncertainty of issuance, and the reduction of the uncertainty of issuance substantially increases the income of IPO issuing companies; Under this issuing mechanism, the IPO subscription and quotation method enables issuers and underwriters to master more information about IPO, thus effectively reducing the underpricing degree when IPO is issued $^{[3]}$.

\section{Analysis of IPO status in China's growth enterprise market}

China Growth Enterprise Market was formally established on October 23, 2009, which was launched after more than ten years of discussion and preparation from all walks of life, and based on the experience of many years of operation of Shenzhen SME Board, based on the experience of establishing GEM market abroad for many years. After the IPO of China Growth Enterprise Market experienced high price and high speed in the early stage, with the weakening of the market, it began to break frequently. Then, due to the continuous downturn of the market, the IPO issuance was suspended after October 9, 2012. During this period, China Growth Enterprise Market Index also experienced great ups and downs, and there was a rare sharp rebound in the year after IPO issuance was suspended. Therefore, the analysis of 
the status quo of IPO on GEM is the focus of this paper.

\subsection{Analysis of the development status of China's growth enterprise market}

Since its establishment in 2009, China's Growth Enterprise Market has developed rapidly in more than two years. On September 30, 2010, the first anniversary of the establishment of the Growth Enterprise Market, there were 150 companies listed on the Growth Enterprise Market, with a total market value of about 500 billion yuan. Since China's securities market has been in a relatively depressed state since 2011, the trend of the GEM market is affected by the trend of the main board, and it is also in a very depressed state. As of October 9, 2012, the GEM index is only 712.70 points, and the overall $\mathrm{P} / \mathrm{E}$ ratio of the GEM is also at a low level. The average $\mathrm{P} / \mathrm{E}$ ratio calculated by the closing price on October 9, 2012 is 35.01 times, and the market earning rate is 2.91 times. The GEM market gradually stabilized after the IPO was suspended on October 9, 2012, and has started a wave of rebound since December 2012 $2^{[4]}$.

\subsection{Analysis on the overall characteristics of China's growth enterprise market}

China's Growth Enterprise Market (GEM) has experienced a very rapid development period since its establishment. The number of listed companies in the three years since the establishment of the GEM has reached 355 (the IPO of the GEM was suspended as of October 9, 2012). That is to say, the average number of companies listed each week until the IPO was suspended. At the same time, the ups and downs of the issuance of labor PO are also very obvious, from the high-speed issuance in the previous three years to the complete suspension of IPO issuance in the latest year, which is rare in the world. One of the biggest characteristics of China's Growth Enterprise Market in the early days of its establishment is its rapid development. Before the IPO was suspended, the IPO issuance was very fast and the number of IPOs was very large $\mathrm{e}^{[5]}$.

\section{Comparative analysis of gem market and other markets}

\subsection{Comparison of listing standards of China growth enterprise market with main board market and small and medium-sized board market}

Since the GEM market adopts the same trading system as the main board market and the small and medium-sized board market in terms of trading system, and the difference in delisting standards, this paper will make a comparison in the discussion on delisting system later, so the comparison here focuses on the comparison of listing conditions of the three markets. By comparing the listing conditions of China's GEM with those of main board market and small and medium-sized board market in detail, it can be found that among the listing requirements of China's GEM market, GEM market not only relaxes the requirements of business scale, profit level and equity, but also has higher requirements for the innovation and future growth of enterprises. Mainly reflected in the following aspects:

First, the Growth Enterprise Market (GEM) has put forward the requirement of maintaining stable and high-speed growth of corporate profits. There are two optional goals in the requirements of the GEM listing standards on the profitability of enterprises. That is to say, in the last two years, it has made a profit, and the net profit cannot be less than 6.5 million yuan. The total operating income in the last two years is not less than 70 million yuan. The growth rate of operating income in the last two years is higher than $40 \%$, and it continues to grow. Compared with the main board market and the small and medium-sized board market, it reduces the requirements of hard quantitative indicators and increases the restrictions on the sustainable growth of enterprises, that is, the business scale standard of enterprises can be relaxed, but it is necessary to maintain high growth and maintain the standard of continuous profit growth. This requirement reflects the importance attached to the growth potential of listed companies in the GEM market ${ }^{[6]}$.

\subsection{Comparative analysis with overseas GEM}

Judging from the current listing standards of the overseas GEM, the biggest characteristic of the overseas GEM lies in the low or even no threshold for listing, while the issuance standards of the Chinese GEM are much more stringent. The explanation for this phenomenon is mainly related to the large number of small and medium-sized enterprises 
in China. It is generally believed that the looser listing standards are conducive to the development of better enterprises to list earlier and to reduce market risks when the Chinese market has abundant listing resources.

\subsection{Compared with the mature American market}

On some specific issues and details, there are still big differences between Chinese and American IPOs, and the differences in IPO listing standards are compared. The Securities Act of the United States in 1933 did not specify specific initial standards, but only required public offering to be registered, and listed some securities and behaviors that did not need registration. On the issue of whether registration is needed, the US Securities Regulatory Commission mainly defines private placement to determine its own regulatory scope, from which a set of rules on private placement are derived. The logic is that private placement does not require registration, while public offering requires registration. In addition, all other standards are left to the exchange, which is defined by the listing standards. Due to the differences in development history and listed company groups, NYSE and NASDAQ have their own set of listing standards. Generally speaking, the listing standard of NYSE is higher, while that of NASDAQ is relatively lower or more flexible.

\section{Suggestions on the development of GEM market}

\subsection{Take the initiative to learn from the successful development experience of overseas GEM market}

In the IPO system and delisting system, we will continue to improve and innovate the system and build a more flexible competitive strategy. At present, there are many new development models and changes in the development of small and medium-sized enterprises in the world. As an important financing platform to serve the development of small and medium-sized enterprises, the GEM needs to constantly adapt to the new development situation of small and medium-sized enterprises, and constantly improve and innovate the system. For example, under the new model of small and medium-sized enterprises, the trend of informatization and miniaturization is more obvious, and the proportion of intangible assets of enterprises is relatively large. Therefore, after the market is more developed, China's Growth Enterprise Market should consider relaxing the listing criteria appropriately, lowering the requirements for enterprise size and paying more attention to study some indicators to measure the development potential of enterprises, so as to give enterprises with high growth potential more listing opportunities. In terms of market echelon construction, for example, two lower-level OTC markets will be established as a supplement to the GEM. Each of the two OTC markets has a clear division of labor. The other is mainly to provide trading venues for delisting companies in the GEM. Through the establishment of the over-the-counter market as the echelon of the GEM market, the IPO issuance system and delisting system will be further developed and improved.

\subsection{Define clear objectives based on market positioning}

At the early stage of the establishment of China's Growth Enterprise Market, we should have an in-depth understanding of the experience and lessons of overseas growth enterprise market system construction as well as the gains and losses of market supervision, and put forward a clear development target for the positioning of China's Growth Enterprise Market in the world's growth enterprise market. The larger scale of China's economy determines that China's Growth Enterprise Market (GEM) must play a decisive role in the world market in the future. At the same time, it should take advantage of this advantage to form a complementary division of labor model with smaller GEM markets such as neighboring ASEAN countries. China's Growth Enterprise Market (GEM) can adopt some simplified measures to attract small and medium-sized enterprises from some countries in the Asia-Pacific region to list in China, and can also encourage some domestic enterprises that cannot meet the requirements of China's GEM to list in nearby markets. This not only strengthens the leading position of China's GEM in the East Asian region, but also takes the nearby smaller GEM as a beneficial supplement to China's GEM and takes it into account in the overall strategic development. 


\section{References}

1. Yang M. Research on the development of China's gem market. Public Investment Guide 2017; (06): 275.

2. Han Y. Problems and suggestions of china's growth enterprise market. China Market 2015; (42): $73-75$.

3. Chen Y. The current situation and countermeasures of the development of China's GEM market. The third compilation of exchange materials of the 2015 annual meeting of china finance association and the 20th national finance theory seminar. China Finance Association 2015.

4. Yang H. Research on the development and construction of growth enterprise market in China. Graduate School of Chinese Academy of Social Sciences 2011.

5. Ruan T. Research on growth enterprise market development in mainland China from an International perspective. Nanchang University 2010.

6. Nie Z. Research on sustainable development of growth enterprise market in China. Wuhan University of Technology 2010. 